\title{
Antibiotic-induced release of endotoxin from bacteria in vitro
}

\author{
HEATHER A. CROSBY*†, J. F. BION†, C. W. PENN $\ddagger$ and T. S. J. ELLIOTT*§ \\ Departments of "Clinical Microbiology and †Intensive Care, Queen Elizabeth Hospital, Birmingham B15 2TH and \\ $\ddagger$ School of Biological Sciences, University of Birmingham, Birmingham B15 2TT
}

\begin{abstract}
Summary. The ability of cefotaxime, ciprofloxacin, piperacillin and tobramycin to cause release of endotoxin was examined in vitro with cultures of Enterobacter cloacae and Escherichia coli. Endotoxin was measured by a quantitative limulus amoebocyte lysate assay and its presence was confirmed by silver staining of the lipopolysaccharide moiety following SDS-PAGE. The morphology of the bacteria during antibiotic exposure was examined by scanning electronmicroscopy. Cefotaxime, ciprofloxacin and piperacillin caused significant endotoxin release, correlating with their ability to affect cell-wall morphology, causing filamentation, wall breakage and cell lysis. In contrast, little endotoxin was released when bacteria were exposed to tobramycin and no morphological changes were observed when bacteria were exposed to bactericidal concentrations of this aminoglycoside. Its antimicrobial spectrum and bactericidal activity make tobramycin an appropriate agent for treatment of sepsis caused by gram-negative bacteria and its lack of propensity to elicit excessive release of endotoxin may avoid exacerbation of endotoxin-related shock in sepsis.
\end{abstract}

\section{Introduction}

Endotoxin (lipopolysaccharide, LPS) is a major component of the cell wall of gram-negative bacteria. It has been implicated in septic shock and multiple organ failure. ${ }^{1}$ These disease processes have an associated mortality rate of $c$. $50 \%$, even where appropriate antibiotics are used and intensive care management is given. ${ }^{2,3}$ A possible explanation for this high mortality is the release of additional endotoxin during antibiotic therapy. ${ }^{4}$ Various in-vitro studies have reported release of significant amounts of endotoxin when bacteria are exposed to bactericidal antibiotics. $^{5-9}$

The present study aimed to determine the amount of endotoxin released from bacteria in vitro when exposed to antibioticsduring logarithmic phase growth. The results were correlated with morphological changes in the bacteria following exposure to the antimicrobial agents.

\section{Materials and methods}

\section{Bacteria}

Clinical isolates of Enterobacter cloacae and Escherichia coli were used; these were identified by the API 20E system (API Laboratory Products, Basingstoke, Hants). They were stored on nutrient agar slopes at $20^{\circ} \mathrm{C}$ and, before use, were subcultured on to nutrient agar containing horse blood $3 \%$ and incubated for $16 \mathrm{~h}$ at $37^{\circ} \mathrm{C}$ in air.

\section{Antibiotics}

The antimicrobial agents used were cefotaxime (Roussel Laboratories, Uxbridge, Middlesex), ciprofloxacin (Bayer, Newbury, Berks), piperacillin (Lederle, Gosport, Hants) and tobramycin (Lilly, Basingstoke, Hants). Minimum inhibitory concentrations (MICs) were determined for each strain by the broth dilution method, ${ }^{10}$ and susceptibilities in disk diffusion tests were determined by the modified Stokes' method. ${ }^{11}$

\section{Endotoxin release studies}

Sterile pyrogen-free plastic-ware was used for all endotoxin assays. Cultures were prepared by inoculating three colonies from the blood-agar plates into $20-\mathrm{ml}$ amounts of warm $\left(37^{\circ} \mathrm{C}\right)$ nutrient broth. The broths were incubated for $1 \mathrm{~h}$ at $37^{\circ} \mathrm{C}$, then diluted 1000 -fold in $20 \mathrm{ml}$ of fresh nutrient broth and incubated for a further $1 \mathrm{~h}$. Antibiotics at $100 \times$ MIC were then added to the cultures, which contained $c$. $10^{4} \mathrm{cfu} / \mathrm{ml}$. Viable counts and the amount of endotoxin in the culture media were measured at $0,1,2$ 
Table I. Endotoxin detection by LAL assay in antibiotic solutions $(100 \times \mathrm{MIC})$ spiked with endotoxin $0.6 \mathrm{EU} / \mathrm{ml}$

\begin{tabular}{lcc}
\hline \multicolumn{1}{c}{ Antibiotic } & $\begin{array}{c}\text { Mean (SD) } \\
\text { amount of } \\
\text { endotoxin } \\
\text { detected } \\
(\mathrm{EU} / \mathrm{ml})\end{array}$ & $\begin{array}{c}\text { Percentage of } \\
\text { endotoxin } \\
\text { detected }\end{array}$ \\
& & \\
\hline Pyrogen-free water & $0.56(0 \cdot 1)$ & 93 \\
Cefotaxime & $0.54(0.2)$ & 90 \\
Ciprofloxacin & $0.45(0.2)$ & 75 \\
Piperacillin & $0.21(0 \cdot 1)$ & 35 \\
Tobramycin & $0.59(0 \cdot 1)$ & 98 \\
\hline
\end{tabular}

Table II. MICs of antibiotics against Ent. cloacae and E. coli

\begin{tabular}{lcc}
\hline \multirow{2}{*}{ Antibiotic } & \multicolumn{2}{c}{ MIC $(\mathrm{mg} / \mathrm{L})$ for } \\
\cline { 2 - 3 } & Ent. cloacae & E. coli \\
\hline Cefotaxime & 0.20 & 0.10 \\
Ciprofloxacin & 0.03 & 0.02 \\
Piperacillin & 1.60 & 1.60 \\
Tobramycin & 0.40 & 1.60 \\
\hline
\end{tabular}

and $3 \mathrm{~h}$ after the addition of the antibiotic. A similar culture without antibiotics acted as a growth control and nutrient broth without bacteria or antibiotics was the medium control for the endotoxin determinations.

To determine released endotoxin, 1-ml portions of the cultures or controls were filtered through a pyrogen-free $0 \cdot 2-\mu \mathrm{m}$ pore polysulphone filter (Acrodisc, Gelman Scientific, Northampton). ${ }^{5}$ The filtrates were immediately stored at $-70^{\circ} \mathrm{C}$, then thawed at room temperature, mixed and serially diluted $10^{2}-10^{4}$-fold in pyrogen-free water for the endotoxin assay.

\section{Endotoxin assay}

A modified chromogenic limulus amoebocyte lysate (LAL) microassay (Coatest Endotoxin Kits, Kabi Diagnostica, Stockholm, Sweden) was used; $50-\mu \mathrm{l}$ amounts of the test samples were added to $50-\mu \mathrm{l}$ amounts of LAL in a sterile microtitration tray. After incubation for $15 \mathrm{~min}$ at $37^{\circ} \mathrm{C}, 100 \mu \mathrm{l}$ of substrate S-2423 (supplied in the LAL assay kit) was added and the samples were incubated for a further $5 \mathrm{~min}$ at $37^{\circ} \mathrm{C}$. The reaction was then stopped with $100 \mu \mathrm{l}$ of acetic acid $20 \%$. Finally, optical densities at $405 \mathrm{~nm}$ were measured on an automated ELISA plate reader (Titertek Multiscan Plus, Flow Laboratories, Buckinghamshire). Appropriate standards of endotoxin $(0.3,0.6$ and $0.9 \mathrm{EU} / \mathrm{ml} ; 1 \mathrm{ng}=12 \mathrm{EU})$, pyrogen-free water and the nutrient broth control without antibiotics or organisms were included on each plate. Endotoxin concentrations in the test samples were estimated from the linear plots of optical density versus endotoxin concentration obtained for the standards.

\section{Antibiotic interference in the LAL assay}

The effect of the antibiotics on the LAL assay was determined. Antibiotics were diluted in pyrogen-free water to $100 \times$ MIC and stock endotoxin was added at a concentration of $0.6 \mathrm{EU} / \mathrm{ml}$. The mixtures were incubated for $1 \mathrm{~h}$ at $37^{\circ} \mathrm{C}$, then mixed well for $3 \mathrm{~min}$. Subsequently, the endotoxin concentrations were determined by LAL assay. This experiment was repeated four times.

\section{Viable counts}

Samples $(0.1 \mathrm{ml})$ of the control and test cultures were obtained and 10-fold dilutions were made in sterile Ringers' solution. Ten- $\mu$ l amounts of appropriate dilutions were then plated in duplicate on to blood agar and colony counts were performed after incubation at $37^{\circ} \mathrm{C}$ for $16 \mathrm{~h}$.

\section{Scanning electronmicroscopy}

The morphology of the Ent. cloacae cultures $\left(10^{6} \mathrm{cfu} / \mathrm{ml}\right)$ after exposure to the antibiotics was determined by scanning electronmicroscopy. Samples of broth culture were removed and the bacteria were resuspended in glutaraldehyde $3 \%$ in $0.2 \mathrm{M}$ sodium cacodylate buffer for $16 \mathrm{~h}$ at $4^{\circ} \mathrm{C}$. The samples were then dehydrated for 10 -min periods in increasing concentrations of ethyl alcohol $(25,50,75,90$ and $100 \%$ ) followed by acetone $100 \%$ for the same period. The bacteria were finally collected on a $0 \cdot 2-\mu \mathrm{m}$ polycarbonate filter (Nucleopore, Agar Scientific, Stansted, Essex), critical-point dried and gold-coated in a sputter coater (EM-Scope 500) at $20 \mathrm{~mA}$ for 2 min. Finally, the bacteria were examined with a Hitachi 2300 electronmicroscope at an accelerating voltage of $25 \mathrm{kV}$.

\section{Visualisation of LPS by silver staining}

Cultures of Ent. cloacae were grown to a density of $10^{8} \mathrm{cfu} / \mathrm{ml}$ in L broth (yeast extract $5 \mathrm{~g}$, tryptone $10 \mathrm{~g}$ and $\mathrm{NaCl} 10 \mathrm{~g}$ in $1 \mathrm{~L}$ of distilled water) ${ }^{12}$ before $1000 \times$ MIC of antibiotic was added at time 0 . The viable counts were determined $0,1.5$ and $3 \mathrm{~h}$ after addition of antibiotic. Samples $(10 \mathrm{ml})$ for SDS-PAGE were taken at the same intervals and were processed as follows. After centrifugation at $10000 \mathrm{~g}$ for $5 \mathrm{~min}$, $1 \mathrm{ml}$ of the supernate was removed and used for LAL assay as above. The remainder of the supernate $(9 \mathrm{ml})$ was added to $30 \mathrm{ml}$ of ethanol and stored at $-20^{\circ} \mathrm{C}$ for at least $30 \mathrm{~min}$. LPS was precipitated at $10000 \mathrm{~g}$ for $15 \mathrm{~min}$ and resuspended in SDS-PAGE sample buffer. ${ }^{13}$ This material was then digested with proteinase $\mathrm{K}^{14}$ before electrophoresis on an acrylamide $12 \%$ mini-gel system as previously described. ${ }^{13}$ Extracts from each antibiotic treatment and control group were run on separate gels.

LPS components were visualised by a silver-staining method, ${ }^{15}$ incorporating the following modifications. The gel was fixed overnight in an aqueous solution of 


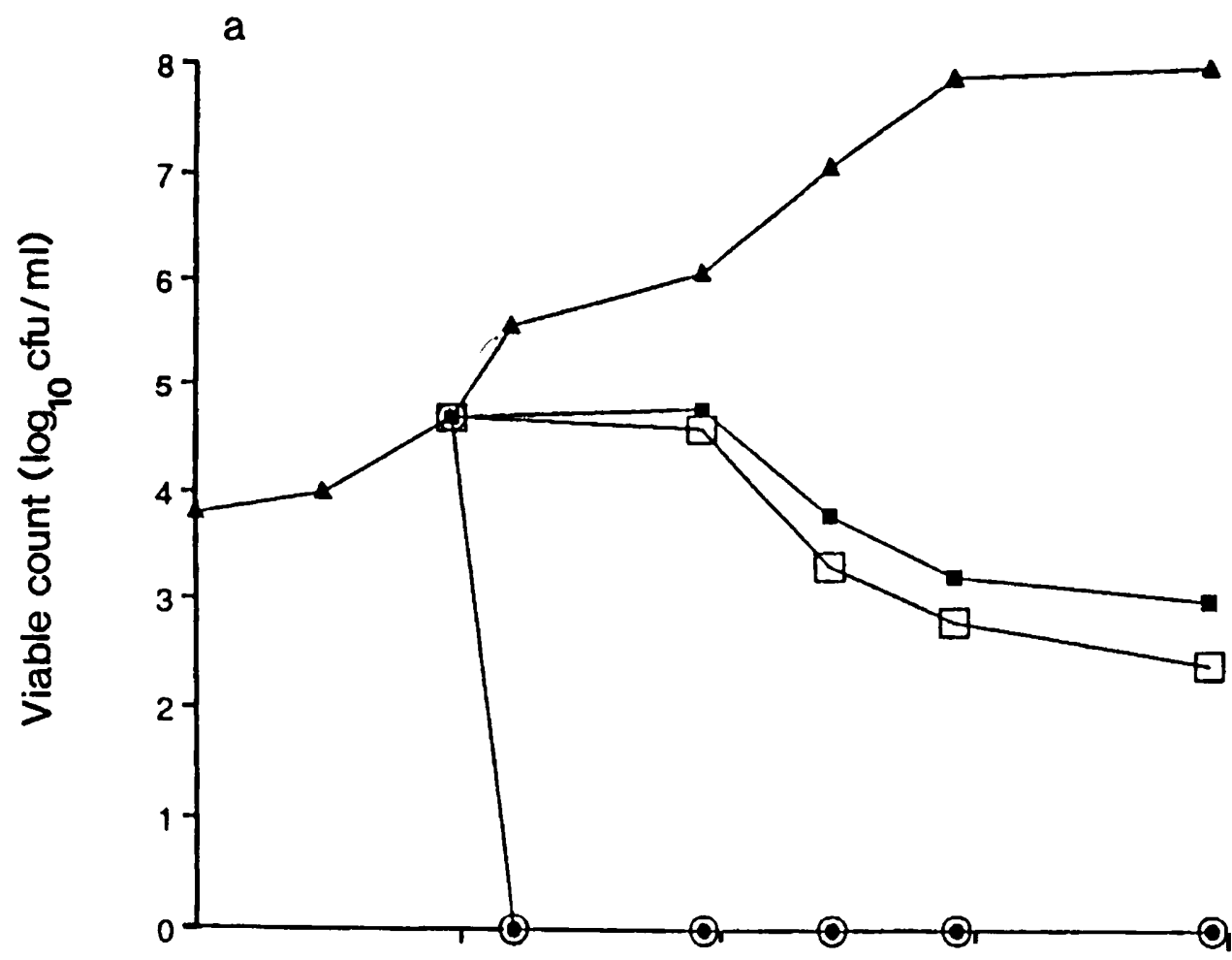

b

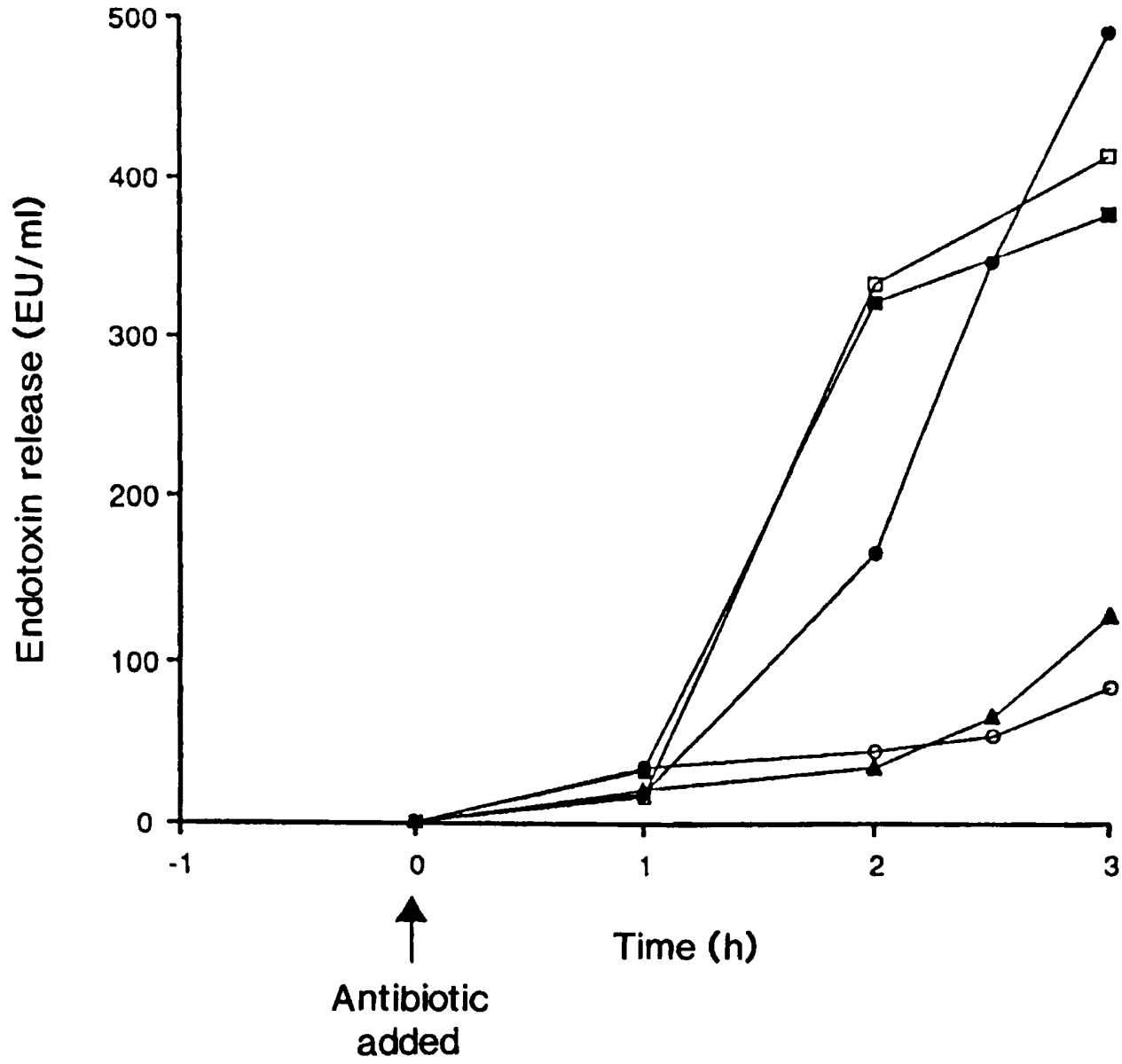

Fig. 1. Effect of antibiotics at $100 \times \mathrm{MIC}$ on a, growth b, release of endotoxin from Ent. cloacae. The antibiotics were added at time 0 : tobramycin $-\Theta$, ciprofloxacin -- , piperacillin $-\boxminus-$, and cefotaxime $-\square-$; no antibiotics were added to the control culture $-\mathbf{\Delta}-$. The results are the means of three separate experiments. 
a

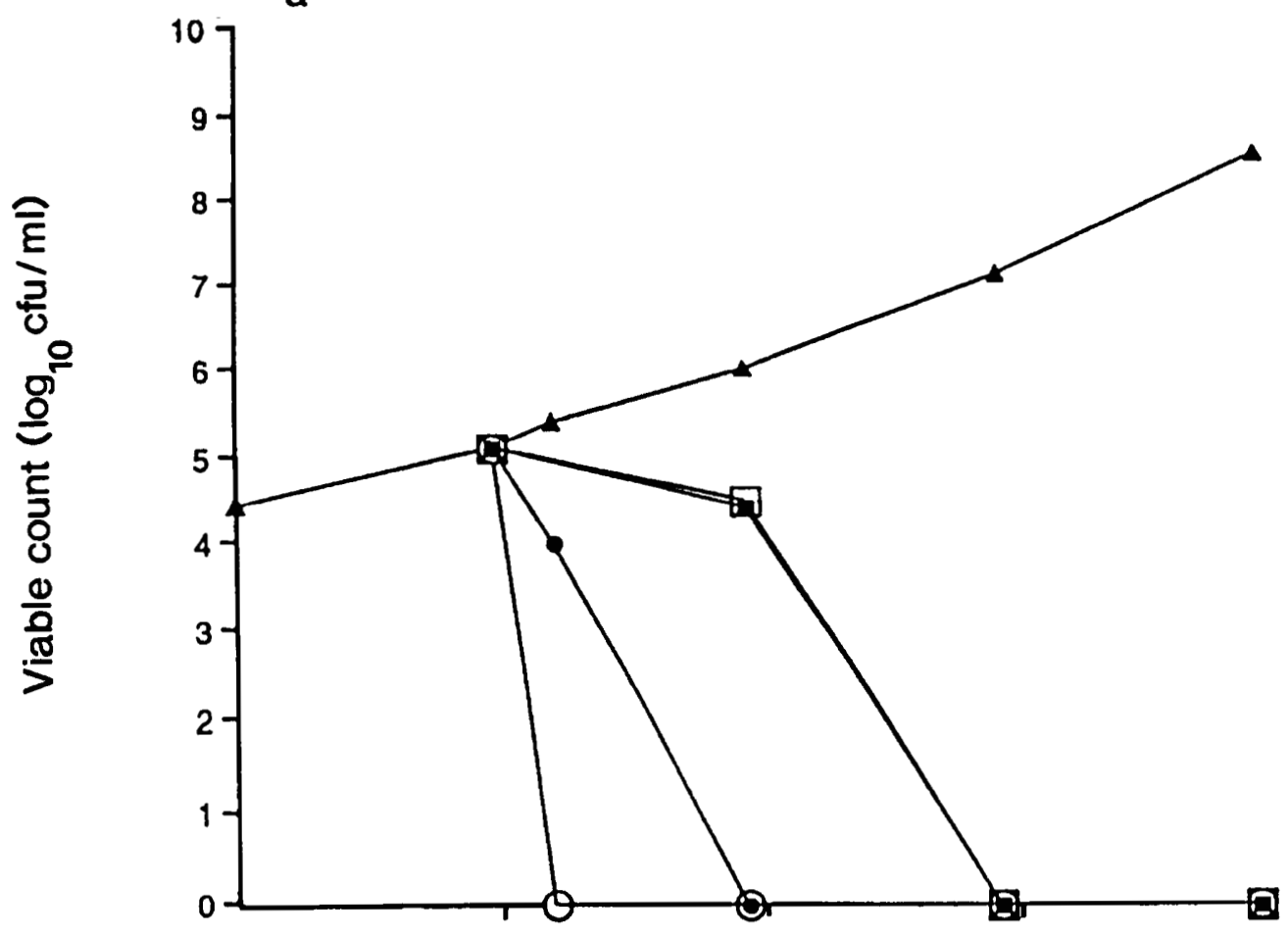

b

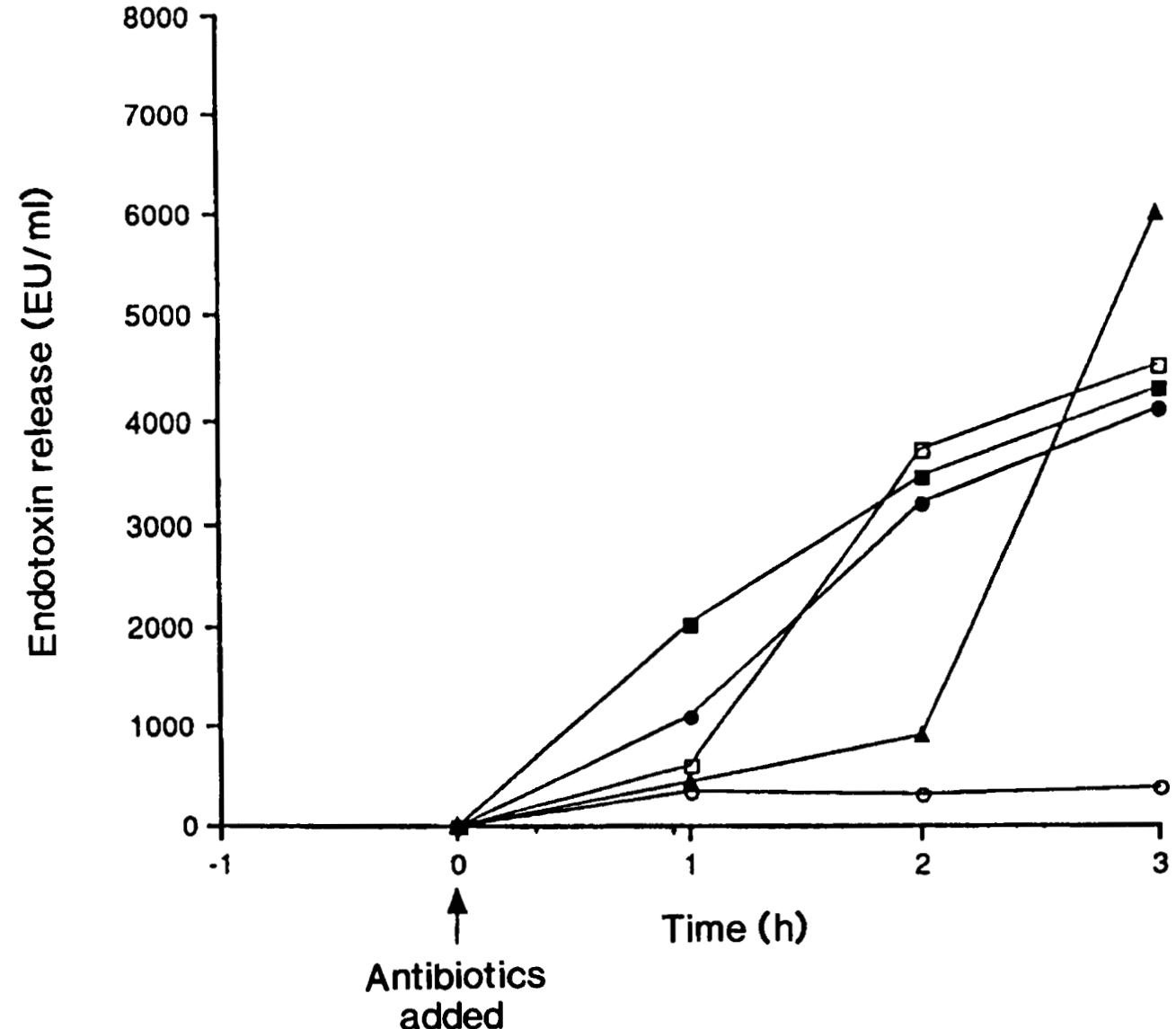

Fig. 2. Effect of antibiotics at $100 \times \mathrm{MIC}$ on $\mathbf{a}$, growth $\mathbf{b}$, release of endotoxin from $E$. coli. The antibiotics were added at time 0 : tobramycin - , ciprofloxacin - - - , piperacillin $-\boxminus-$, and cefotaxime $-\square-$; no antibiotics were added to the control culture $-\mathbf{A}-$. The results are the means of three separate experiments.

methanol $45 \% \mathrm{v} / \mathrm{v}$ and acetic acid $10 \% \mathrm{v} / \mathrm{v}$. The oxidiser consisted of periodic acid $0.7 \%$ dissolved in aqueous methanol $45 \% \mathrm{v} / \mathrm{v}$ and acetic acid $5 \% \mathrm{v} / \mathrm{v}$.
The development of staining intensity was stopped by placing the gel in acetic acid $1 \% \mathrm{v} / \mathrm{v}$ for $3 \mathrm{~min}$ before transfer to distilled water. 


\section{Statistical methods}

Data were analysed by variance of $\log$ values of endotoxin concentrations.

\section{Results}

\section{Antibiotic interaction of the LAL assay}

Cefotaxime, ciprofloxacin and tobramycin at $100 \times$ MIC did not interfere with the detection of endotoxin by LAL assay. However, endotoxin detection was significantly $(\mathrm{p}<0.001)$ inhibited by piperacillin at $100 \times \mathrm{MIC}$, with recorded endotoxin levels appearing $c$. $65 \%$ below the control values (table I).

\section{Antibiotic susceptibility}

The MICs of the antibiotics are shown in table II. All the bacteria were sensitive to the antimicrobial agents investigated.

\section{Viable counts and endotoxin release}

The viable counts and endotoxin release data for Ent. cloacae and E. coli are presented in figs. 1 and 2,

Table III. Viable counts and endotoxin release when Ent. cloacae and $E$. coli were exposed to cefotaxime, ciprofloxacin, piperacillin and tobramycin for $3 \mathrm{~h}$

\begin{tabular}{|c|c|c|c|c|}
\hline \multirow[b]{2}{*}{ Treatment } & \multicolumn{2}{|c|}{ Ent. cloacae } & \multicolumn{2}{|c|}{ E. coli } \\
\hline & $\begin{array}{l}\text { Viable } \\
\text { count* } \\
\left(\log _{10}\right. \\
\text { cfu } / \mathrm{ml})\end{array}$ & $\begin{array}{l}\text { Endotoxin } \\
\text { release* } \\
(\mathrm{EU} / \mathrm{ml})\end{array}$ & $\begin{array}{l}\text { Viable } \\
\text { count } \\
\left(\log _{10}\right. \\
\mathrm{cfu} / \mathrm{ml})\end{array}$ & $\begin{array}{c}\text { Endotoxin } \\
\text { release* } \\
(\mathrm{EU} / \mathrm{ml})\end{array}$ \\
\hline Control & $\begin{array}{c}8 \\
(0 \cdot 5)\end{array}$ & $\begin{array}{l}131 \\
(30)\end{array}$ & $\begin{array}{c}8 \cdot 5 \\
(1 \cdot 3)\end{array}$ & $\begin{array}{l}6019 \\
(781)\end{array}$ \\
\hline Cefotaxime & $\begin{array}{c}3 \\
(0 \cdot 1)\end{array}$ & $\begin{array}{l}380 \\
(70)\end{array}$ & $\begin{array}{c}0 \\
(0)\end{array}$ & $\begin{array}{c}4519 \\
(1019)\end{array}$ \\
\hline Ciprofloxacin & $\begin{array}{c}0 \\
(0)\end{array}$ & $\begin{array}{l}493 \\
(38)\end{array}$ & $\begin{array}{c}0 \\
(0)\end{array}$ & $\begin{array}{l}4119 \\
(619)\end{array}$ \\
\hline Piperacillin & $\begin{array}{c}2 \cdot 4 \\
(0 \cdot 2)\end{array}$ & $\begin{array}{l}415 \\
(40)\end{array}$ & $\begin{array}{c}0 \\
(0)\end{array}$ & $\begin{array}{c}4319 \\
(1519)\end{array}$ \\
\hline Tobramycin & $\begin{array}{c}0 \\
(0)\end{array}$ & $\begin{array}{c}87 \\
(48)\end{array}$ & $\begin{array}{c}0 \\
(0)\end{array}$ & $\begin{array}{c}389 \\
(159)\end{array}$ \\
\hline
\end{tabular}

* Mean (SD) of three experiments.

Table IV. Endotoxin released per bacterium after exposure of $E$. coli to antibiotics for $3 \mathrm{~h}$

\begin{tabular}{lccc}
\hline Antibiotic & $\begin{array}{c}\text { Endotoxin } \\
\text { release } \\
(\mathrm{EU} / \mathrm{ml})\end{array}$ & $\begin{array}{c}\text { Viable } \\
\text { count } \\
(\mathrm{cfu} / \mathrm{ml})\end{array}$ & $\begin{array}{c}\text { Endotoxin/ } \\
\text { cfu } \\
(\mathrm{EU} / \mathrm{cfu})\end{array}$ \\
\hline Control & 6019 & $1 \times 10^{8 *}$ & $6 \times 10^{-5}$ \\
Cefotaxime & 4519 & $1 \times 10^{5 \dagger}$ & $4.5 \times 10^{-2}$ \\
Ciprofloxacin & 4119 & $1 \times 10^{5} \dagger$ & $4.1 \times 10^{-2}$ \\
Piperacillin & 4319 & $1 \times 10^{5} \dagger$ & $4.3 \times 10^{-2}$ \\
Tobramycin & 389 & $1 \times 10^{5} \dagger$ & $3.9 \times 10^{-3}$
\end{tabular}

\footnotetext{
* Viable counts at $3 \mathrm{~h}$.
}

+ Viable counts at $0 \mathrm{~h}$. respectively. Each figure shows mean data for three separate experiments.

The endotoxin levels recorded for the nutrient broth controls remained constant over the study period and were subtracted from the results obtained for the bacterial cultures.

Exposure of Ent. cloacae (fig. 1) to ciprofloxacin $0.3 \mathrm{mg} / 1$ or tobramycin $4 \mathrm{mg} / 1$ resulted in a marked decline in viable count within $30 \mathrm{~min}$. The viable counts of bacteria in the presence of cefotaxime $2 \mathrm{mg} / 1$ or piperacillin $16 \mathrm{mg} / 1$ remained unchanged during the first hour of exposure, and then declined slowly during the following $2 \mathrm{~h}$.

Endotoxin was released slowly from Ent. cloacae control cultures during logarithmic growth and was released in larger amounts during stationary phase. Cefotaxime, piperacillin and ciprofloxacin caused a rapid and significant $(\mathrm{p}<0.05)$ release of endotoxin from Ent. cloacae, occurring 1-2 h after the addition of the antibiotic and reaching a maximum of $400 \mathrm{EU} / \mathrm{ml}$ at $3 \mathrm{~h}$ (table III). During a 3-h exposure period, tobramycin did not significantly increase endotoxin release compared to that seen with the control bacteria $(p>0 \cdot 05)$. Differences between the endotoxin release caused by tobramycin and that caused by the other antibiotics were significant $(\mathrm{p}<0.05)$.

A similar response was demonstrated with $E$. coli cultures: thus, tobramycin caused no increase in endotoxin release $(p>0.05)$ whereas cefotaxime, piperacillin and ciprofloxacin induced increased release of endotoxin after exposure for $1 \mathrm{~h}(\mathrm{p}<0.01$, fig. 2 ). However, E. coli cultures that had not been exposed to antibiotics showed increasing endotoxin release after growth for $2 \mathrm{~h}$ and, by $3 \mathrm{~h}$, the amount of endotoxin released appeared to be greater than in any of the cultures treated with antibiotics. Nevertheless, when the bacterial numbers were taken into account, the amount of endotoxin released per bacterium remained lower for the control culture than for the antibiotic-exposed bacteria (table IV). When the data were analysed on this basis there was no significant difference in the amount of endotoxin released per bacterium at $3 \mathrm{~h}$ between the control culture and that exposed to tobramycin $(p>0.05)$, but there was a significant (c. 700-fold) increase for the cefotaxime-, ciprofloxacin- or piperacillin-treated bacteria compared to the control or tobramycin-treated organisms $(\mathrm{p}<0.025)$. These results also suggest that the $0 \cdot 2-\mu \mathrm{m}$ filters did not themselves cause release of endotoxin from the control bacteria, as has been described in previous studies. ${ }^{5}$

\section{Morphological effects of antibiotics on Ent. cloacae}

Ent. cloacae cells were rod-shaped, with smooth wall morphology, as examined by scanning electronmicroscopy. Cefotaxime $(20 \mathrm{mg} / \mathrm{l})$ or piperacillin $(160 \mathrm{mg} / \mathrm{l})$ caused filamentation within $1 \mathrm{~h}$ (fig. 3a). During the following hour, elongation of the filaments occurred, with some bacterial lysis (fig. 3b). Exposure 

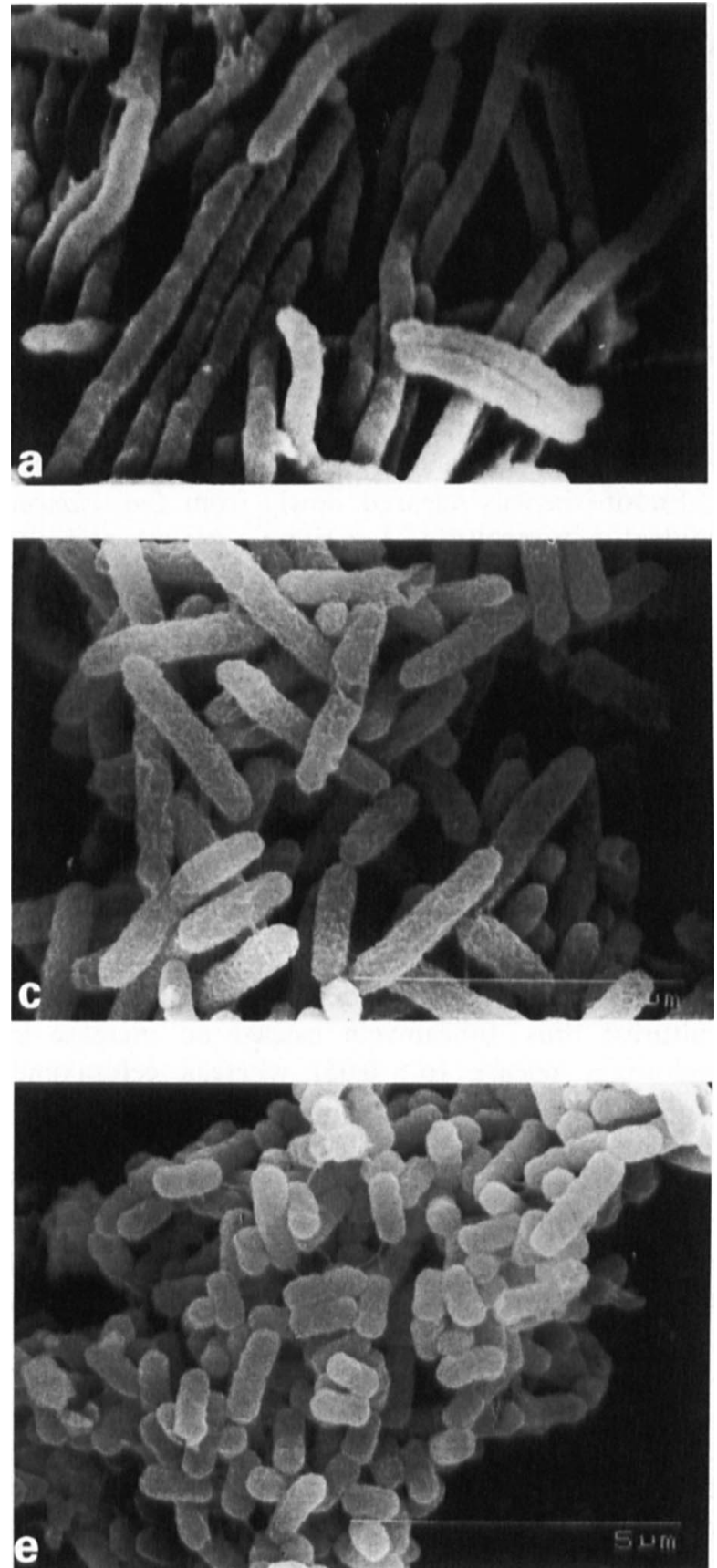

to ciprofloxacin $(3 \mathrm{mg} / \mathrm{l})$ for $1 \mathrm{~h}$ caused some bacterial filamentation and by $2 \mathrm{~h}$, terminal cell lysis was evident (fig. 3c). The morphology of the bacteria after exposure to tobramycin $(40 \mathrm{mg} / \mathrm{l})$ did not appear different from that of the control cells (fig. $3 \mathrm{~d}$ and e).

\section{Visualisation of LPS by silver staining}

Experimentation with reference LPS from $E$. coli O111:B4 showed that increasing the LPS concentration resulted in an enhanced band intensity on SDSPAGE gels. The silver stain method has been reported to have a detection limit of $5 \mathrm{ng}(60 \mathrm{EU})$ of LPS/lane $;{ }^{16}$ therefore, to raise the amount of LPS released to a level detectable by staining, the bacterial
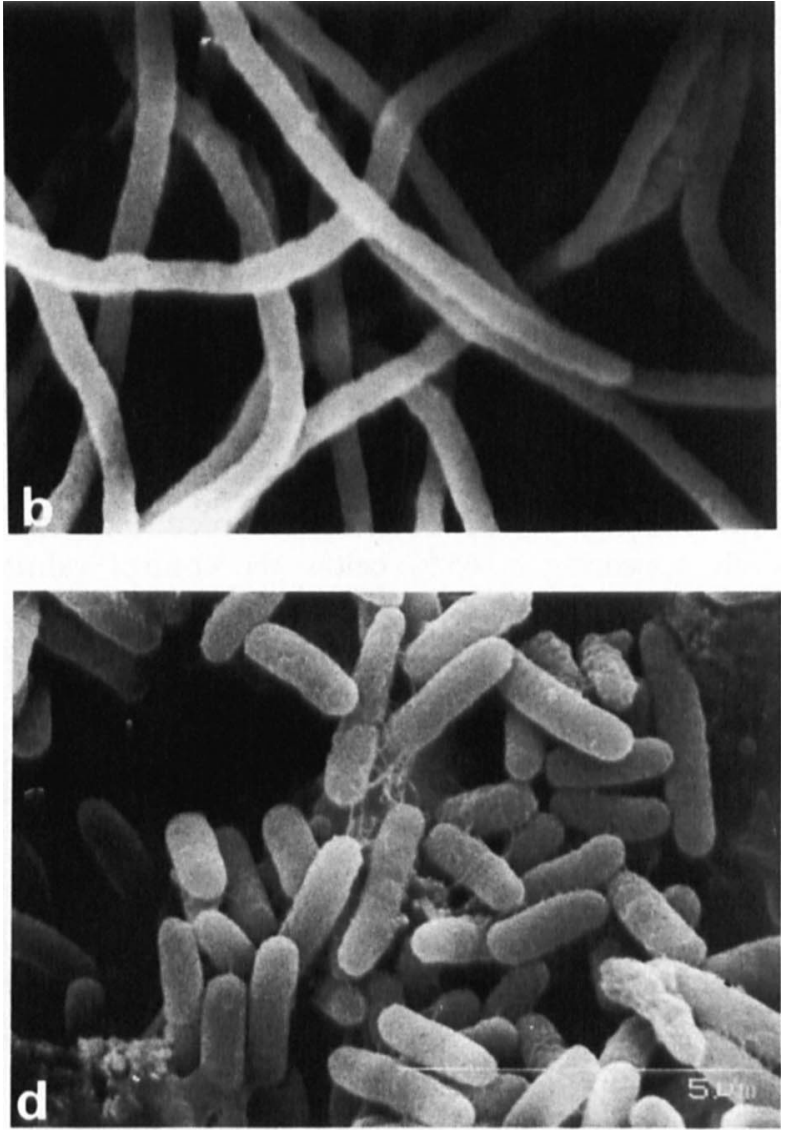

Fig. 3. Scanning electronmicrographs of Ent. cloacae exposed to: a, piperacillin $160 \mathrm{mg} / \mathrm{L}$ for $1 \mathrm{~h}$; b, cefotaxime $20 \mathrm{mg} / \mathrm{L}$ for $2 \mathrm{~h}$; c, ciprofloxacin $3 \mathrm{mg} / \mathrm{L}$ for $2 \mathrm{~h}$; d, tobramycin $40 \mathrm{mg} / \mathrm{L}$ for $2 \mathrm{~h}$; e, no antibiotic for $2 \mathrm{~h}$. Bar, $5 \mu \mathrm{m}$.

concentrations in the cultures were increased relative to those employed when LPS was measured by LAL assay. The antibiotic concentration was also increased, albeit not fully in proportion to the cell concentration, to $1000 \times$ MIC rather than $100 \times$ MIC.

After exposure of Ent. cloacae cultures to cefotaxime, piperacillin or ciprofloxacin, the amount of LPS released into the supernate was increased compared to the control, as shown by greater staining intensity, whereas the staining intensity of LPS from tobramycin-treated bacteria did not differ from that of the control. The profiles of the LPS released following exposure of Ent. cloacae cultures to ciprofloxacin and tobramycin are shown in fig. 4. 


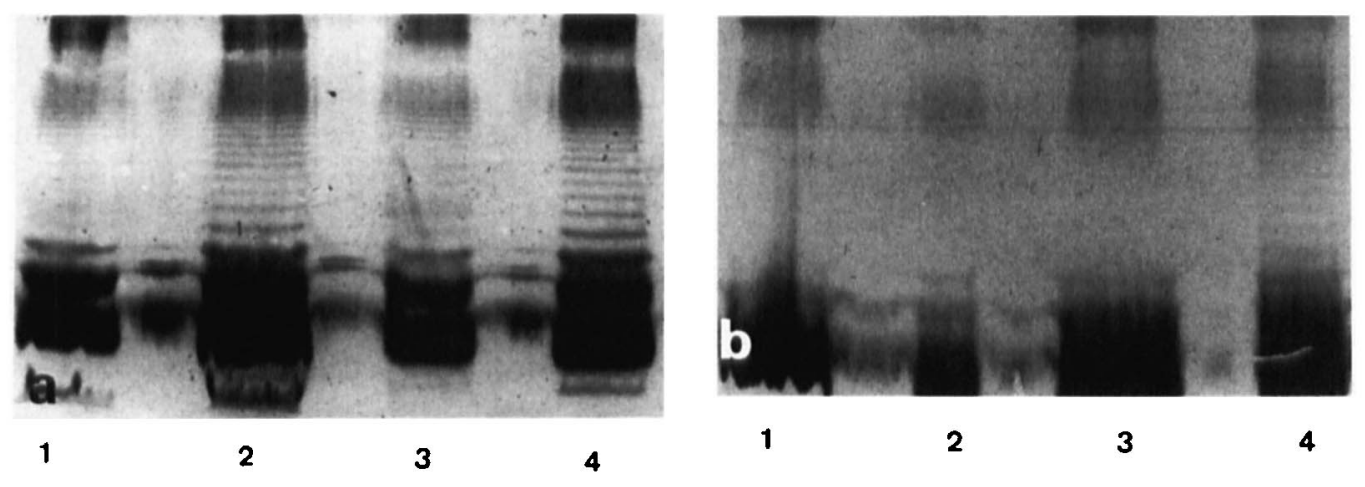

Fig. 4. Silver stains of LPS of Ent. cloacae following SDS-PAGE: profiles for bacteria exposed to (a) ciprofloxacin, (b) tobramycin. Lanes 1 and 3 , control bacteria; 2 and 4 , bacteria treated with antimicrobial agents for 1.5 and $3 \mathrm{~h}$, respectively. The amount of silver-stained LPS was greater in the ciprofloxacin-treated bacteria than in those exposed to tobramycin.

\section{Discussion}

The role of endotoxin as one of the mediators of septic shock in gram-negative septicaemia is increasingly recognised as an important clinical problem. ${ }^{17,18}$ Antibiotic therapy during such sepsis may cause additional endotoxin release, thereby exacerbating shock. Therefore, antibiotic selection may be of prime importance. The present study demonstrated that endotoxin is released from Ent. cloacae and E. coli after exposure to cefotaxime, ciprofloxacin and piperacillin, but not during exposure to tobramycin. The increase in endotoxin release after $1 \mathrm{~h}$ was correlated with the morphological changes induced by the antibiotics: filamentation and lysis were induced by cefotaxime, ciprofloxacin and piperacillin, whereas tobramycin had no apparent effect on gross morphology. These observations can, in turn, be related to the actions of these agents. ${ }^{19-21}$ Endotoxin release from the Ent. cloacae and E. coli strains followed similar time courses during exposure to cefotaxime, ciprofloxacin or piperacillin. However, the time course of bactericidal activity differed between ciprofloxacin and the $\beta$-lactams. Ciprofloxacin-treated bacteria were killed rapidly and no viable organisms were detected after $30 \mathrm{~min}$, whereas cefotaxime and piperacillin were bacteriostatic during the first hour of exposure and then bactericidal. It would appear that endotoxin release from the cefotaxime- or piperacillin-treated bacteria is directly related to a decrease in the number of viable bacteria and may reflect the $\beta$-lactam activity on the cell wall. Filamentation, with an increase in biomass and with concurrent synthesis of LPS occurred before bacteriolysis. Lysis of these filaments would then release more endotoxin than would be liberated by lysis of unicells. Such a process has recently been demonstrated ${ }^{22}$ with several other antibiotics that, like piperacillin and cefotaxime, bind to PBP-3 and induce filamentation, but not rapid lysis, in gram-negative rods. Endotoxin release from the ciprofloxacin-treated bacteria in the present study may have resulted from lysis of the terminal cell walls of non-viable bacteria. In comparison, bactericidal con- centration of tobramycin did not cause additional endotoxin release and no alteration was observed in bacterial morphology.

The specificity of the LAL reaction for endotoxin and interference by antibiotics have previously been questioned. $^{23}$ Cefotaxime, ciprofloxacin and tobramycin did not interfere with this assay; however, the presence of piperacillin caused a reduction in the amount of endotoxin detected (table I). The reasons for this inhibition are unclear at present. However, the observation supports the need for confirmatory tests such as SDS-PAGE and silver staining of LPS to demonstrate that endotoxin is being measured and not an antibiotic interaction.

It has been demonstrated previously that tobramycin or gentamicin can reduce the amount of endotoxin detected by LAL assay. ${ }^{24}$ In another study, ${ }^{25}$ neutralisation of endotoxin with tobramycin occurred after $3 \mathrm{~h}$. These effects, unlike that with piperacillin, were not seen in the present study. It is possible that the incubation period of $1 \mathrm{~h}$ used in the current study was not optimal for neutralisation of endotoxin. However, the low degree of endotoxin release from tobramycin-exposed bacteria was confirmed by SDS-PAGE, suggesting that the LAL assay was not distorted by endotoxin neutralisation. It seems possible that the lack of cell wall destruction by tobramycin resulted in retention of endotoxin.

The extent to which different antibiotics induce endotoxin release from gram-negative bacteria is also relevant to current theories of the pathogenesis of multiple organ failure in critically ill patients. Splanchnic ischaemia, complicating various shock states, may cause an increase in intestinal mucosal permeability, ${ }^{26}$ with consequent leak of intra-luminal endotoxin across the bowel wall and into the systemic circulation. ${ }^{27}$ Systemic or enteral antibiotics that facilitate endotoxin release could be disadvantageous in these circumstances. For example, selective antibiotic decontamination of the digestive tract (SDD) has been recommended for the prevention of bacterial colonisation of the gastrointestinal and respiratory tracts of critically-injured patients undergoing mechanical 
ventilation ${ }^{28}$ and has been suggested as a means of eradicating gut-derived endotoxin. ${ }^{29}$ The enteral component of this regimen includes tobramycin and polymyxin, both of which have been shown to bind to lipid A. ${ }^{8}$ However, the recommended concurrent systemic use of cefotaxime for SDD could counteract these potential benefits, and might explain why the regimen consistently reduces infection rates without significantly improving survival. ${ }^{30}$

Our findings suggest that it may be appropriate to use an aminoglycoside for those systemic infections in

\section{References}

1. Morrison DC, Ryan JL. Endotoxins and disease mechanisms Annu Rev Med 1987; 38: 417-432.

2. Parrillo JE, Parker MM, Watanson C et al. Septic shock in humans: advances in the understanding of pathogenesis, cardiovascular dysfunction, and therapy. Ann Intern Med 1990; 113: 227-242.

3. Ispahani P, Pearson NJ, Greenwood D. An analysis of community and hospital-acquired bacteraemia in a large teaching hospital in the United Kingdom. $Q J \mathrm{Med} 1987$ 63: 427-440.

4. Shenep JL, Mogan KA. Kinetics of endotoxin release during antibiotic therapy for experimental Gram-negative sepsis. $J$ Infect Dis 1984; 150: 380-388.

5. Cohen J, McConnell JS. Release of endotoxin from bacteria exposed to ciprofloxacin and its prevention with polymyxin B. Eur J Clin Microbiol 1986; 5: 13-17.

6. Goto H, Nakamura S. Liberation of endotoxin from Escherichia coli by addition of antibiotics. Jpn J Exp Med 1980; 50: 35-43.

7. Stokes DC, Shenep JL, Fishman M, Hildner WK, Bysani GK, Rufus K. Polymyxin B prevents lipopolysaccharideinduced release of Tumor Necrosis Factor- $\alpha$ from alveolar macrophages. $J$ Infect Dis 1989; 160: 52-57.

8. Rifkind D. Prevention by polymyxin $\mathbf{B}$ of endotoxin lethality in mice. J Bacteriol 1967; 93: 1463-1464.

9. Van Den Berg C, De Neeling AJ, Schot CS, Hustinx WNM, Wemer J, De Wildt DJ. Delayed antibiotic-induced lysis of Escherichia coli in vitro is correlated with enhancement of LPS release. Scand J Infect Dis 1992; 24: 619-627.

10. Greenwood D. Antibiotic sensitivity testing. In: Antimicrobial chemotherapy, 2nd ed. Oxford, Oxford University Press. 1989: 91-100.

11. Stokes EJ, Ridgway GL. Antimicrobiol drugs. In: Clinical microbiology, 6th ed. London, Edward Arnold. 1987: 199-240.

12. Maniatis T, Fritsch EF, Sambrook J. Molecular cloning. A laboratory manual. Cold Spring Habour, NY, Cold Spring Harbour Laboratory. 1982: 440.

13. Laemmli UK. Cleavage of structural proteins during the assembly of the head of the bacteriophage T4. Nature 1970 ; 227: 680-685.

14. Hitchcock PJ, Brown TM. Morphological heterogeneity among Salmonella lipopolysaccharide chemotypes in silverstained polyacrylamide gels. $J$ Bacteriol 1983; 154: 269-277.

15. Hancock I, Poxton I. Bacterial cell surface techniques. Chichester, John Wiley and Sons. 1988: Appendix 1, 281.

16. Tsai C-M. The analysis of lipopolysaccharide (endotoxin) in meningococcal polysaccharide vaccines by silver staining which release of further LPS would have severe consequences. The nephrotoxic potential of aminoglycosides should be carefully considered in each case. Recently a study has shown that endotoxin can enhance the nephrotoxicity of aminoglycosides in rats. ${ }^{31}$ Therefore, further work is essential to understand fully the potential and effects of endotoxin release for the various antibiotic regimens used in the treatment of infections.

We thank Bayer, Lederle, Lilly and Roussel for support of this study.

following SDS-polyacrylamide gel electrophoresis. $J$ Biol Standard 1986; 14: 25-33.

17. McCartney AC, Banks JG, Clements GB, Sleigh JD, Tehrani M, Ledingham IM. Endotoxaemia in septic shock : clinical and postmortem correlations. Intensive Care Med 1983; 9 . $117-122$.

18. Michie HR, Manogue KR, Spriggs DR et al. Detection of circulating tumour necrosis factor after endotoxin administration. $N$ Engl J Med 1988; 318: 1481-1486.

19. Reeves DS, Bywater MJ, Holt HA, White LO. In-vitro studies with ciprofloxacin, a new 4-quinolone compound. $J$ Antimicrob Chemother 1984; 13: 333-346.

20. Elliott TSJ, Shelton A, Greenwood D. The response of Escherichia coli to ciprofloxacin and norfloxacin. $J \mathrm{Med}$ Microbiol 1987; 23 : 83-88.

21. Davis BD. Mechanism of bactericidal action of aminoglycosides. Microbiol Rev 1987; 51: 341-350.

22. Dofferhoff ASM, Nijland $\mathbf{J H}$, de Vries-Hospers HG, Mulder POM, Weits J, Bom VJJ. Effects of different types and combinations of antimicrobial agents on endotoxin release from Gram-negative bacteria: An in vitro and in vivo study. Scand J Infect Dis 1991; 23: 745-754.

23. Bayston KF, Cohen J. Bacterial endotoxin and current concepts in the diagnosis and treatment of endotoxaemia. $J \mathrm{Med}$ Microbiol 1990; 31: 73-83.

24. Artenstein AW, Cross AS. Inhibition of endotoxin reactivity by aminoglycosides. $J$ Antimicrob Chemother 1989; 24: $826-828$

25. Focà A, Matera G, Iannello D, Berlinghieri MC, Liberto MC Aminoglycosides modify to in vitro metachromatic reaction and murine generalised shwartzman phenomenon induced by Salmonella minnesota R595 lipopolysaccharide. Antimicrob Agents Chemother 1991; 35: 2161-2164.

26. Marston A, Bulkley GB, Fiddian-Green RG, Haglund UH (eds). Splanchnic ischaemia and multiple organ failure London, Edward Arnold. 1989.

27. Olofsson P, Nylander G, Olsson P. Endotoxin: routes of transport in experimental peritonitis. Am J Surg 1986;151: 443-446.

28. Stoutenbeek CP, van Saene HKV, Miranda DR, Zandstra DF. The effect of selective decontamination of the digestive tract on colonisation and infection rate in multiple trauma patients. Intensive Care Med 1984; 10 : 185.

29. Bion JF. Endotoxinaemia in the critically ill patient. Current Anaesthesia and Critical Care 1991; 2: 161-166.

30. Vandenbroucke-Grauls CMJE, Vandenbroucke JP. Effect of selective decontamination of the digestive tract on respiratory tract infections and mortality in the intensive care unit. Lancet 1991 ; 338 : 859-862.

31. Ngeleka M, Beauchamp D, Tardif D, Auclair P, Gourde P, Bergeron MG. Endotoxin increases the nephrotoxic potential of gentamicin and vancomycin plus gentamicin. $J$ Infect Dis 1990; 161: 721-727. 